\title{
Profil Fitokimia Ekstrak Etanol Bunga Kasumba Turate (Carthamus tinctorius L.) yang Berpotensi Sebagai Antimalaria
}

\author{
Rini Hamsidi ${ }^{* 1}$, Aty Widyawaruyanti ${ }^{2,3}$, Achmad Fuad Hafid ${ }^{2,3}$, Wiwied Ekasari ${ }^{2}$, Muhammad Hajrul \\ Malaka $^{1}$, Henny Kasmawati ${ }^{1}$, Nur Illiyyin Akib ${ }^{1}$, Wahyuni ${ }^{1}$, Sabarudin ${ }^{1}$
}

${ }^{1}$ Fakultas Farmasi Universitas Halu Oleo, Kampus Hijau Bumi Tridharma Anduonohu, Kendari 93232

${ }^{2}$ Departemen Farmakognosi dan Fitokimia, Fakultas Farmasi Universitas Airlangga, Jl. Dharmawangsa Dalam, Surabaya 60286

${ }^{3}$ Institute of Tropical Disease Universitas Airlangga, Kampus C Universitas Airlangga, Jl. Mulyorejo Surabaya 60115

E-mail: rinihamsidi@gmail.com

\begin{abstract}
Abstrak
Bunga Kasumba turate (Carthamus tinctorius Linn) dari suku Asteraceae merupakan tumbuhan obat tradisional etnis Sulawesi Selatan yang secara empiris digunakan dalam pengobatan campak. Ekstrak etanol dari kasumba turate memberikan peningkatan aktivitas imunoglobulin $\mathrm{G}$ (IgG) dan aktivitas imunoglobulin A (IgA) yang sangat signifikan. Penelitian menunjukkan ekstrak etanol bunga $C$. Tinctorius $\mathrm{L}$ memiliki potensi sebagai antimalaria secara in vitro dengan nilai $\mathrm{IC}_{50}$ sebesar $1,06 \mu \mathrm{g} / \mathrm{ml}$. Sampel bunga $C$. tinctorius L. kering sebanyak $3 \mathrm{Kg}$ dicacah hingga menjadi serbuk sebanyak 870 gram kemudian diekstraksi secara maserasi dengan menggunakan pelarut etanol $80 \%$. Hasil maserasi dipekatkan dengan vacuum rotary evaporator pada suhu $50^{\circ} \mathrm{C}$ sehingga diperoleh ekstrak kental sebanyak 178,7gram. Profil fitokimia menunjukkan ekstrak etanol bunga $C$. tinctorius $\mathrm{L}$. mengandung senyawa metabolit antara lain saponin, terpenoid, flavonoid, tanin dan antrakuinon.
\end{abstract}

Kata kunci: Skrining, ekstrak, kasumba turate, obat tradisional, antimalaria

\section{Pendahuluan}

Indonesia merupakan salah satu negara yang masih berisiko terhadap malaria. Sebagian besar daerah di Indonesia merupakan daerah endemik infeksi malaria, Indonesia bagian timur seperti Papua, Maluku, Nusa Tenggara, Sulawesi, Kalimantan dan bahkan beberapa daerah di Sumatra seperti Lampung, Bengkulu, Riau. Angka kesakitan malaria di Indonesia pun dilaporkan meningkat dari tahun ke tahun [1]. Tumbuh dan menyebarnya resistensi terhadap semua obat antimalaria lapis pertama yang dipakai pada pengobatan dan pencegahan malaria telah menimbulkan banyak masalah pada program penanggulangan malaria, sehingga perlu dilakukan pencarian senyawa baru obat antimalaria terutama yang berasal dari bahan alam [2], yang potensial dan aman untuk manusia [3]. Kontribusi penelitian bahan alam terhadap penemuan antimalaria baru tidak diragukan dengan adanya produk bahan alam yang memiliki potensi antiplasmodia yang telah dievaluasi secara in vitro, sitotoksisitas, dan beberapa telah diuji secara in vivo [4].

Malaria merupakan penyakit infeksi yang disebabkan oleh parasit Plasmodium yang ditularkan melalui gigitan nyamuk Anopheles betina. Parasit Plasmodium yang masuk ke dalam tubuh manusia, akan berkembang biak dalam hati kemudian menginfeksi sel darah merah. Empat spesies Plasmodium yang menginfeksi manusia, yaitu P. falciparum (menyebabkan malaria tropika), $P$. malariae (menyebabkan malaria kuartana), $P$. vivax dan $P$. ovale (menyebabkan malaria tersiana). Namun dari keempat spesies tersebut, $P$. falciparum yang paling patogen dan bertanggungjawab untuk hampir semua kematian akibat malaria [5].

Senyawa alam dari tumbuhan dapat dijadikan senyawa antimalaria alternatif pengganti obat malaria yang sudah resistan terhadap parasit [6]. Tanaman obat di Indonesia dapat dijadikan sebagai antimalaria, yang bersifat antiplasmodia dan juga bersifat meningkatkan daya tahan tubuh terhadap serangan penyakit malaria. Adanya pemberian tanaman obat tersebut terbukti dapat memperpanjang umur mencit yang terserang malaria dengan mencegah kerusakan pada hati dan limpa [7].

Bunga Kasumba turate (Carthamus tinctorius Linn) dari suku Asteraceae merupakan tumbuhan obat tradisional yang secara empiris digunakan masyarakat Sulawesi Selatan untuk pengobatan campak yang diberikan dengan cara diseduh dengan air panas untuk meningkatkan sistem daya tahan tubuh atau sistem imun pada pasien. Penelitian sebelumnya menunjukkan ekstrak etanol dari bunga kasumba turate $(C$. tinctorius $\mathrm{L}$.) memiliki aktivitas antimalaria yang poten secara in vitro dengan nilai $\mathrm{IC}_{50}$ sebesar $1,06 \mu \mathrm{g} / \mathrm{ml}[8,9]$. Oleh karena itu, penelitian ini bertujuan untuk mengetahui profil fitokimia yang terkandung dalam ekstrak etanol bunga kasumba turate $(C$. tinctorius L.) yang diperoleh dengan metode maserasi. 


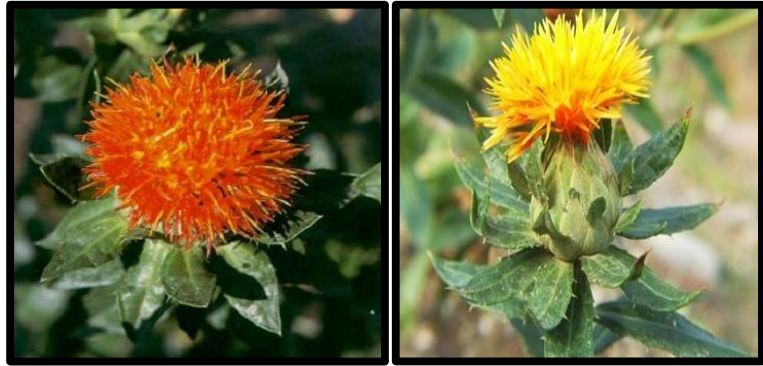

Gambar 1. Tanaman C. tinctorius [10]

\section{Metode}

\subsection{Ekstraksi}

Bunga kasumba turate diperoleh dari perkebunan kasumba turate di Kabupaten Bone, Sulawesi Selatan. Metode ekstraksi menggunakan maserasi dengan etanol dalam wadah tertutup selama $3 \times 24$ jam [11]. Filtrat dikumpulkan lalu diuapkan menggunakan rotary evaporator $\left(50^{\circ} \mathrm{C}, 77\right.$ mbar) hingga diperoleh ekstrak etanol kental [9].

\subsection{Skrining Fitokimia}

Identifikasi senyawa yang ekstrak etanol bunga kasumba turate terdiri atas:

a. Identifikasi alkaloid menggunakan pengembang kloroform:etil asetat (1:1) atau etil asetat:metanol:air (6:4:2), dengan penampak noda pereaksi dragendorf. Jika timbul noda warna jingga maka menunjukkan adanya alkaloid dalam ekstrak.

b. Identifikasi flavonoid menggunakan pengembang butanol : asam asetat glasial : air (4:1:5), dengan penampak noda uap amonia atau pereaksi sitrat borat. Jika timbul noda warna kuning intensif menunjukkan adanya flavonoid.

c. Identifikasi tanin menggunakan pengembang kloroform:etil asetat : asam formiat (0,5:9:0,5), dengan penampak noda pereaksi $\mathrm{FeCl}_{3}$. Jika timbul noda warna hitam menunjukkan adanya tanin.

d. Identifikasi saponin menggunakan pengembang nheksan : etil asetat (4:1), dengan penampak noda anisaldehid asamsulfat atau antimon klorida. Jika timbul noda warna merah ung (ungu) untuk anisaldehid asam sulfat dan warna merah muda untuk antimon klorida menunjukkan adanya sapogenin dalam ekstrak.

e. Identifikasi terpenoid menggunakan pengembang nheksana:etilasetat (4:1), dengan penampak noda anisaldehid asam sulfat. Jika timbul noda warna merah ungu atau ungu maka menunjukkan adanya senyawa terpenoid.

f. Golongan antarkuinon: digunakan pengembang benzena : etil asetat : asam asetat glasial (75:24:1), dengan penampak noda pereaksi $\mathrm{FeCl}_{3}$. Jika timbul noda warna kuning, kuning coklat, merah ungu atau hijau ungu maka menunjukkan adanya senyawa antrakuinon.

\subsection{Karakterisasi Ekstrak}

Karakterisasi ekstrak meliputi penetapan kadar air, kadar abu, kadar sari larut etanol dan kadar sari larut air [12].

\section{Penetapan kadar sari larut air}

Lebih kurang 1 gram ekstrak dilarutkan dengan 100 ml air, menggunakan labu bersumbat sambil berkali-kali dikocok selama 6 jam pertama kemudian dibiarkan selama 18 jam. Filtrat disaring dan $20 \mathrm{ml}$ diuapkan hingga kering dalam cawan dangkal berdasar rata yang telah ditara, sisa dipanaskan pada suhu 105 oC hingga bobot tetap. Kadar dihitung dalam persen sari yang larut dalam air, dihitung terhadap bahan yang dikeringkan di udara [12].

\section{Penetapan kadar sari larut etanol}

Lebih kurang 1 gram ekstrak dengan $100 \mathrm{ml}$ etanol 95\%, menggunakan labu bersumbat sambil berkali-kali dikocok selama 6 jam pertama dan kemudian dibiarkan selama 18 jam. Filtrat disaring dengan cepat untuk menghindarkan penguapan etanol $95 \%$ dan $20 \mathrm{~mL}$ diuapkan hingga kering dalam cawan dangkal berdasar rata yang telah ditara, sisa dipanaskan pada suhu 105oC hingga bobot tetap. Kadar dihitung dalam persen sari yang larut dalam etanol $95 \%$ dihitung terhadap bahan yang dikeringkan di udara [12].

\section{Hasil dan Pembahasan}

Metode ekstraksi yang digunakan dalam penelitian ini adalah maserasi menggunakan pelarut etanol. Maserat dikumpulkan dan dipekatkan menggunakan rotary evaporator untuk memisahkan pelarut etanol. Suhu yang digunakan pada proses ini tidak boleh terlalu tinggi untuk menghindari rusaknya komponen dalam sampel yang tidak tahan terhadap panas. Hasilnya berupa ekstrak kental berwarna cokelat kemerahan sebanyak 71 gram.

Ekstrak etanol kental kemudian diuji kandungan metabolit sekundernya secara kualitatif seperti yang disajikan dalam tabel berikut.

Tabel 1. Hasil skrining fitokimia ekstrak etanol bunga kasumba turate

\begin{tabular}{lc} 
Golongan Senyawa & Hasil Identifikasi \\
\hline Alkaloid & + \\
Saponin & + \\
Terpenoid & + \\
Flavonoid & + \\
Tanin & + \\
Antarkuinon & + \\
\hline
\end{tabular}

Keterangan: (+) mengandung senyawa yang diuji

(-) tidak mengandung senyawa yang diuji

Hasil uji menunjukkan berbagai metabolit sekunder seperti alkaloid, saponon, terpenoid, flavonoid, tannin, maupun antrakuinon terkandung dalam bunga kasumba turate. Kandungan kimia dalam $C$. tinctorius yang telah dilaporkan sejauh ini antara lain turunan serotonin, 
flavonoid, kinobeone A, hidroksi safflor kuning A, eritroalkana-6, 8-diol, dan tinctormine, lignan, alkohol triterpen, polisakarida, dan alkaloid [13, 14, 15].

Tabel 2. Hasil karakterisasi ekstrak etanol tanaman kasumba turate

\begin{tabular}{ll}
\hline \multicolumn{1}{c}{ Jenis karakterisasi } & \multicolumn{1}{c}{ Hasil } \\
\hline $\begin{array}{l}\text { Parameter spesifik } \\
\text { Identitas }\end{array}$ & \\
Nama latin tumbuhan & $\begin{array}{l}\text { Carthamus tinctorius } \mathrm{L} . \\
\text { Bagian yang digunakan }\end{array}$ \\
$\begin{array}{l}\text { Nama Indonesia tumbuhan } \\
\text { Bunga kasumba turate }\end{array}$ & \\
Organoleptis & Kental \\
Bentuk & Merah kehitaman \\
Warna & Khas \\
Bau & Sepat \\
Rasa & \\
\hline Parameter non spesifik & $3 \%$ \\
Kadar sari larut air & $4 \%$ \\
Kadar sari larut etanol & \\
\hline
\end{tabular}

Ekstrak etanol bunga $C$. tintorius lebih larut di dalam etanol daripada di dalam air. Kadar zat terlarut ini merupakan uji kemurnian ekstrak untuk mengetahui jumlah terendah kandungan kimia ekstrak yang terlarut dalam pelarut yang digunakan.

\section{Kesimpulan}

Ekstrak etanol bunga kasumba turate $C$. tinctorius L. yang diperoleh dari metode maserasi memiliki kandungan fitokimia antara lain saponin, terpenoid, flavonoid, tanin dan antrakuinon.

\section{Ucapan Terima Kasih}

Penulis menyampaikan terima kasih kepada Kementerian Riset, Teknologi, dan Pendidikan Tinggi RI yang mendanai penelitian ini melalui skema Hibah Penelitian Kerjasama Antar Perguruan Tinggi Tahun 2017.

\section{Daftar Pustaka}

1. Kepmenkes RI. Buletin Jendela Data dan Informasi Kesehatan: Epidemiologi malaria di Indonesia. Jakarta: Kementerian Kesehatan RI, 2011; 7-8.

2. Raharjo A, Ekasari W, Hafid AF. Uji Aktivitas Antimalaria Ekstrak Air Daun Johar (Cassia siamea Lamk) Terhadap Plasmodium berghei Secara In vivo. Jurnal Farmasi dan Ilmu Kefarmasian Indonesia, 2014, 1(1).

3. Widyawaruyanti A, Zaini NC, Syafruddin. Mekanisme dan Aktivitas Antimalaria dari Senyawa Flavonoid yang
Diisolasi dari Cempedak (Artocarpus champeden), Jurnal Bina Praja, 2011, 13 (2)

4. Maslachah L, Yoes PD, Chairul AN, Loeki EF. Profil Fenotipik Plasmodium falciparum Galur Papua 2300 Akibat Paparan Antimalaria Artemisinin in Vitro, MKB, 2014, 47(1);1-9.

5. Olasehinde GI, Ayanda OI, Ajayi AA, Nwabueze AP. InVivo Antiplasmodial Activity of Crude N-Hexane and Ethanolic Extracts of Moringa oleifera (LAM.) Seeds on Plasmodium berghei, International Journal of Medicinal Plant Research, 2012, 1(5);49

6. Batista R, Júnior AJS, de Oliveira AB. Plant-Derived Antimalarial Agents: New Leads and Efficient Phytomedicines. Part II. Non-Alkaloidal Natural Products, Molecules, 2009, 14.

7. Hutomo R, Sutarno, Winarno W, Kusmardi. Uji Antimalaria Ekstrak Buah Morinda citrifolia dan Aktivitas Makrofag pada Mencit (Mus musculus) setelah Diinfeksi Plasmodium berghei. Biofarmasi, 2005, Vol 3(2).

8. Hamsidi R, Akib NI, Wahyuni. In Vitro Antimalarial Activity of Ethanol and Methanol Extract Carthamus tinctorius L. Proceeding Molecular and Cellular Life Sciences: Infectious Diseases, Biochemistry and Structural Biology MCLS 2015. ISBN 978-602-14292-4-2. p. 30-33.

9. Hamsidi R, Widyawaruyanti A, Hafid AF, Ekasari W, Kasmawati H, Akib NI, Wahyuni, Malaka MH. In Vitro antimalarial activity of chloroform, n-butanol, and ethyl acetate fractions of ethanol extracts of Carthamus tinctorius Linn. Flowers. Asian J Pharm Clin Res, 2018, 11(2); 121123, http://dx.doi.org/10.22159/ajpcr.2018.v11i2.15856

10. Li D, Mündel HH. Safflower (Carthamus tinctorius L.): Promoting the Conservation and Use of Underutilized and Neglected Crops 7, Institute of Plant Genetics and Crop Plant Research, Gatersleben/International Plant Genetic Resources Institute, 1996.

11. Harborne JB. Metode Fitokimia Penuntun Cara Modern Menganalisis Tumbuhan, Edisi 2. Terjemahan: Padmawinata K dan Soediro I. Bandung: Penerbit ITB, 1987.

12. Departemen Kesehatan RI. Parameter Standar Umum Ekstrak Tumbuhan Obat. Jakarta: Direktorat Jenderal POM, 2000.

13. Arpornsuwan T, Changsri K, Roytrakul S, Punjanon T. The Effects of the Extracts from Carthamus tinctorius L. on Gene Expression Related to Cholesterol Metabolism in Rats, Songklanakarin Journal of Science and Technology, 2010, 32(2); 130

14. Mandade R. Protective Effects of Carthamus tinctorius on Streptozotocin-Induced Diabetic Complications in Rats and the Possible Morphological Changes in the Liver and Kidney, International Journal of Science Innovations and Discoveries, 2012, 2(5);503

15. Jun MS, Ha YM, Kim HS, Jang HJ, Kim YM, Lee YS, Kim HJ, Seo HG, Lee JH, Lee SH, Chang KC. Anti-Inflammatory Action of Methanol Extract of Carthamus tinctorius Involves in Heme Oxygenase-1 Induction, J. of Ethnopharmacology, 2011, 133;524 